\title{
GEOCHRONOLOGY OF THE GRANITOID HOSTED SALAMANGONE GOLD DEPOSIT, LOURENÇO DISTRICT, AMAPÁ, BRAZIL.
}

\section{SONIA APARECIDA ABISSI NOGUEIRA ${ }^{1}$, JORGE SILVA BETTENCOURT ${ }^{2}$ AND COLOMBO CELSO GAETA TASSINARI ${ }^{3}$}

\begin{abstract}
The Salamangone deposit occurs in the Lourenço Gold District, Amapá. It is associated to Paleoproterozoic metamorphosed supracrustal rocks and a calc-alkaline complex. The deposit lies within a metaluminous to weakly peraluminous, calc-alkaline tonaliticgranodioritic pluton. The Au-mineralization consists of an epigenetic quartz-vein system, enriched in Au and As, and structurally controlled by a ductile-brittle shear zone. U-Pb zircon analyses of tonalite gave a crystallization age of $2.16 \pm 0.13 \mathrm{Ga}$, whereas $\mathrm{Sm}-\mathrm{Nd} \mathrm{T}$ model ages of tonalite and granodiorite range from 2.24 and $2.34 \mathrm{Ga}$. e $(\mathrm{T})$ vary from +2.88 to +3.02 . Additional whole rock Rb-Sr isochron ages on granitoids yielded values in the range of 2.17 to $2.28 \mathrm{Ga}$, with ${ }^{\mathrm{d}}{ }^{8} \mathrm{Sr} /{ }^{86} \mathrm{Sr}$ initial ratio of 0.702 . The isotopic data and geochemical signature of granitoids suggest that the Lourenco region, as well as the neighboring areas in French Guyana, represents a vast area largely floored by accreted juvenile arc terranes without evidence of Archean crust contamination, being related to the development of a calc-alkaline magmatic arc, which was produced within the Maroni-Itacaíunas Province, during a major Paleoproterozoic orogenic event.
\end{abstract}

Keywords: Amazonian Craton, Paleoproterozoic, tonalite-trondhjemite-granodiorite(TTG), gold mineralization.

\section{INTRODUCTION}

The Salamangone Au-deposit is the most important among the several Au-deposits and prospects which have been mined in the Lourenço Gold District-Amapá. Here the Au-quartzvein system is contained within a calc-alkaline granitoid complex (tonalite-granodiorite), and the ore is enclosed within a shear zone. This association is not much different from what has been reported in comparable Canadian Archean terranes (Callan and Spooner 1989, 1998), Australia (Cassidy et al. 1998), Paleoproterozoic terranes of French Guyana (Milési et al. 1995) and West Africa (Milési et al. 1992, Oberthür et al. 1998).

The geochronology of the State of Amapá is poorly documented and up to the present the Lourenço region has received little attention. In this paper emphasis is placed on the geochronological data on the granitoids hosted Salamangone Gold Deposit, which constitute part of the ongoing Ph.D. thesis of S.A.A. Nogueira, at the Instituto of Geociências of the University of São Paulo.

GEOLOGICAL SETTING The Lourenço Au-District is located in the central portion of the State of Amapá, within the Maroni-Itacaiúnas Province, 2.2-1.95Ga (Teixeira et al. 1989), of the Amazonian Craton (Almeida 1978). According to Terraconsult (1986) and Lima et al. (1991) the Lourenço region is included in the Lourenço Metamorphic Suite which consists of high-grade partially migmatized metamorphic supracrustal rocks and calc-alkaline (TTG-type) complexes. All these rocks are cross-cut by a ductile-brittle shear zone, to which the Salamangone and a variety of mineralized au-quartz-vein are associated (Fig. 1). The Lourenço Metamorphic Suite together with the Vila Nova Group (Lima et al. 1974) mostly recognized in the southern part of the State of Amapá, Paramaca Group (Paramaca Series of Choubert 1974) comprised within the boundary of Amapá and French Guyana, could represent Paleoproterozoic supracrustal sequences.

THE SALAMANGONE GOLD DEPOSIT The deposit is contained within a ductile-brittle shear zone striking N50-60 $\mathrm{W}$ and dipping 55 to $70^{\circ} \mathrm{NE}$, which is over $350 \mathrm{~m}$ long and has an average thickness of about 50m (Fig.1). It lies within a calc-alkaline, metaluminous to slightly peraluminous tonalite to granodiorite pluton. It is characterized by high contents of incompatible trace elements and LREE, showing a geochemical signature of volcanic arc granites-VAG (Pearce et al. 1984). The primary mineralization consists of ribbonquartz veins enriched in $\mathrm{Au}$ and As, exhibiting relatively low enrichment of $\mathrm{Ag}, \mathrm{Pb}, \mathrm{Cu} \mathrm{Bi}$, and $\mathrm{Au}$-quartz infilling in microfractures. $\mathrm{Au}$ is associated with sulfides, mainly arsenopyrite. The deposit is epigenetic in character and structurally controlled by a ductile-brittle shear zone, very similar to analogous epigenetic Au-deposits discussed by Cassidy et al. (1998).

ANALYTICAL TECHNIQUES AND SAMPLING Sm-Nd, Rb$\mathrm{Sr}$ and $\mathrm{K}-\mathrm{Ar}$ isotopic analyses were carried out at the Geochronological Research Center of São Paulo University (CPGeOUSP), whereas $\mathrm{U}-\mathrm{Pb}$ and $\mathrm{Pb}-\mathrm{Pb}$ at the Institute of Precambrian
Geology and Geochronology, Russian Academy of Sciences (IPGGRAS), St-Petersburg, Russia.

$\mathrm{Rb}$ and $\mathrm{Sr}$ contents were determined by $\mathrm{X}$-ray fluorescence, and $\mathrm{Sm}$ and $\mathrm{Nd}$ values by isotopic dilution. The spectrometric readings were done on a VG-354 mass-spectrometer. $\mathrm{K}$ contents were determined by a flame spectrometer and Ar values by a gaseous source massspectrometer, Reynolds MS-1, according to the standard analytical procedures described by Amaral et al. (1966). $\mathrm{Pb}-\mathrm{Pb}$ analyses were undertaken on a IPGG-RAS Finnigan MAT 2618 collector mass spectrometer. Zircon analyses and air-abrasion treatment followed the method of $\operatorname{Krogh}(1973,1982)$. All samples were spiked with a ${ }^{235} \mathrm{U}$ ${ }^{208} \mathrm{~Pb}$ mixed tracer and the total blanks were $0.05-0.1 \mathrm{ng} \mathrm{Pb}$ and $0.005 n g \mathrm{U}$. The $\mathrm{Rb}-\mathrm{Sr}, \mathrm{U}-\mathrm{Pb}$ and $\mathrm{Pb}-\mathrm{Pb}$ isotopic data were regressed using the program of Ludwig (1999). Isochrons with a large MSWD value, had these age calculations based on Model 3. The ages were calculated with $1_{\mathrm{Rb}}=1.42 \times 10^{-1}$ anos $^{-1}$, proposed by Steiger and Jäger (1977). Sm-Nd model ages ( $\mathrm{T}_{\mathrm{Rb}}$ ) were calculated using the depleted mantle model of De Paolo (1988).

The sampling sites for this study are illustrated in Fig. 1. The samples consist dominantly of a hornblende-biotite- tonalite, with biotite-granodiorite and aplite.

RESULTS AND DISCUSSION $\mathrm{Pb}$ isotope analyses and $\mathrm{Pb}$, Th and $U$ contents of samples of the granodiorite and tonalite of the Salamangone area are presented in Tables 1 and 2. Zircons extracted from the tonalite were analyzed by the U-Pb method, and analytical points are plotted on a Concordia Diagram defining a discordia line (Fig. 2), with upper and lower intercepts of $2.16 \pm 0.13 \mathrm{Ga}$ and $0.48 \pm$ $0.13 \mathrm{Ga}$ respectively. The first age is interpreted as the crystallization age of the plutonism, while the second one has no geological meaning due to extreme $\mathrm{Pb}$ loss by continuous-diffusion processes. Furthermore the same granitoid define a $\mathrm{Pb}-\mathrm{Pb}$ whole-rock isochron (Fig. 3), which yields an age of $1995 \pm 260 \mathrm{Ma}$ with a $\mathrm{m}$ value $=8.4(\mathrm{MSWD}=0.7)$

Sm-Nd depleted mantle model ages calculated for both tonalite and granodiorite gave ages of 2.24 and $2.34 \mathrm{Ga}$ respectively (Fig. 4). $\varepsilon$ values calculated to $2.1 \mathrm{Ga}$ range from +2.88 to +3.02 (Table 3 ), which indicate that magmatic precursors are significantly older (by 100 $200 \mathrm{Ma}$ ) than tonalite and granodiorite U-Pb age estimates. It is also suggested that the Lourenço region represents a vast area of juvenile continental crust with no contamination with Archean crust. In this way the isotopic data, along with the $\mathrm{U}-\mathrm{Pb}$ age estimates, reinforce previous interpretation that consider the Lourenço area as part of the Maroni-Itacaiunas Geochronological Province, whose crustal evolution took place during a major Paleoproterozoic accretion event between 2.25 and $1.95 \mathrm{Ga}$.

The U-Pb and $\mathrm{Pb}-\mathrm{Pb}$ study has been complemented by $\mathrm{Rb}-\mathrm{Sr}$ analyses. The analytical results are listed in Table 4. Six whole-rock samples from the granodiorite gave a $\mathrm{Rb}-\mathrm{Sr}$ isochronic age of $2169 \pm$ $89 \mathrm{Ma}$, an ${ }^{87} \mathrm{Sr} /{ }^{86} \mathrm{Sr}$ initial ratio of $0.7023 \pm 0.0004$ and a MSWD value of 1.3 (Fig. 5), while five whole-rock samples from the tonalite yield a $\mathrm{Rb}-\mathrm{Sr}$ age of $2278 \pm 240 \mathrm{Ma}$ with ${ }^{87} \mathrm{Sr} /{ }^{86} \mathrm{Sr}$ initial ratio of

1 Instituto Geológico, Secretaria do Meio Ambiente do Estado de São Paulo. Avenida Miguel Stefano, 3900, CEP 04301-903. e-mail: snogueira@igeologico.sp.gov.br

2 Departamento de Mineralogia e Geotectônica, Instituto Geociências/USP. Caixa Postal 11348, CEP 05422-970. e-mail:jsbetten@usp.br

3 Centro de Pesquisas Geocronológicas - CPGeo, Instituto Geociências/USP. Caixa Postal 11348, CEP 05422-970. e-mail:ccgtassi@usp.br 


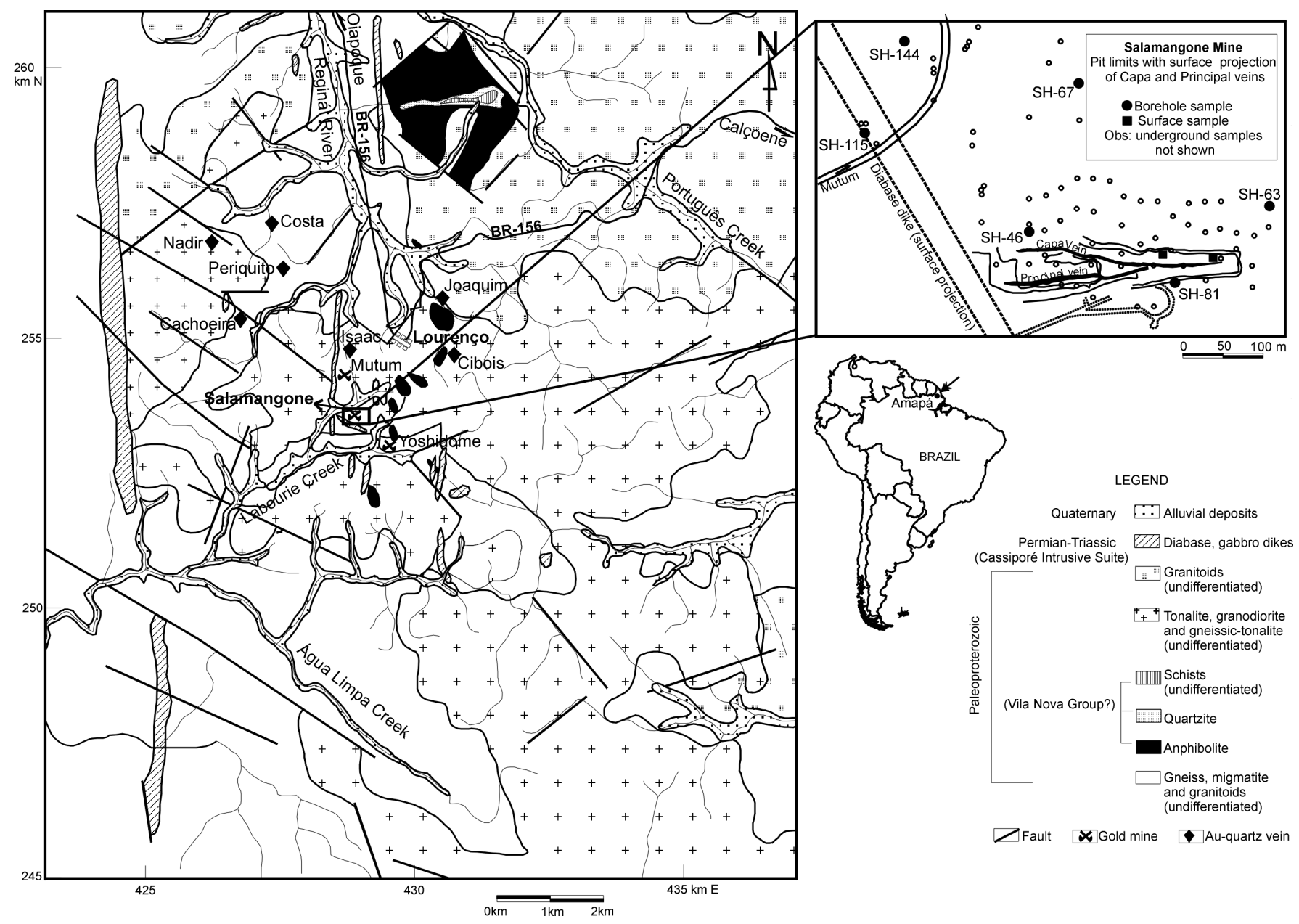

Figure 1-Geological sketch map of the Lourenço Gold District, modified and complemented after Terraconsult (1986).

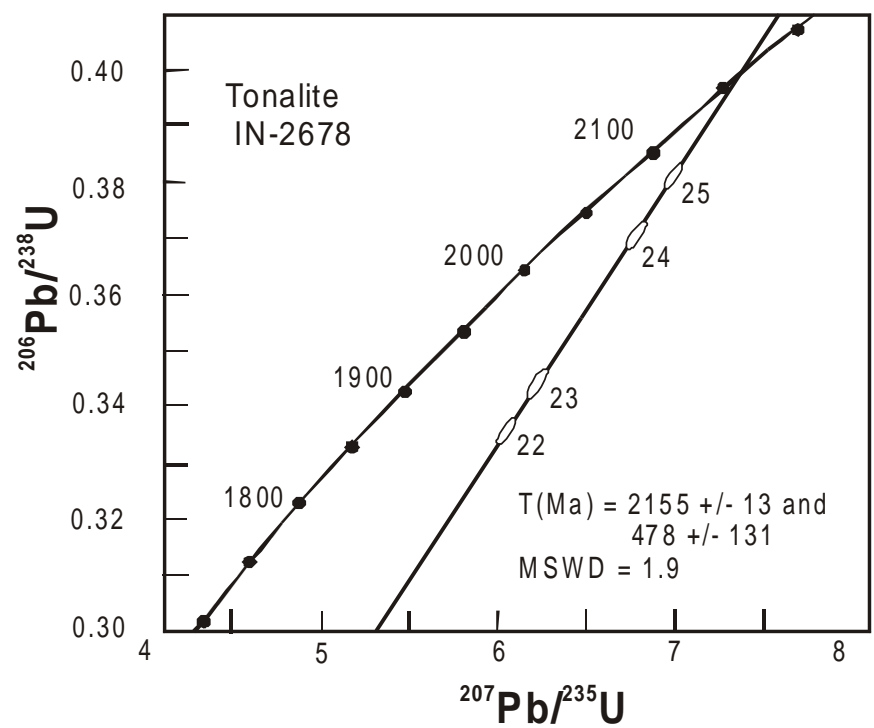

Figure 2-U-Pb concordia diagram for tonalite (host rock of the Salamangone mineralization).

$0.7019 \pm 0.0012$ and MSWD $=0.58$ (Fig. 6). The low initial ${ }^{87} \mathrm{Sr} /{ }^{86} \mathrm{Sr}$ ratios obtained for both contemporaneous granodiorite and tonalite are in close agreement, suggesting that their parental magmas were derived from similar source.

Younger magmatic activities in the Lourenço region are represented by aplitic-veins which cross-cut the $2.1 \mathrm{Ga}$ granitoids. Samples from the aplites yield a Rb-Sr whole-rock isochronic age of $1976 \pm 200 \mathrm{Ma}$



Figure 3-Pb-Pb whole rock isochron for tonalite and granodiorite (host rocks of the Salamangone mineralization).

with an initial ${ }^{87} \mathrm{Sr} /{ }^{86} \mathrm{Sr}$ ratio of $0.708 \pm 0.021$ and MSWD $=0.13$ (Fig. 7). The high error of the Sr initial ratio, due to the lack of analytical points close to the origin, is responsible for the high uncertainty of the age.

Samples from the altered tonalite were chosen to try to date the mineralization episode. The analytical points, plotted in the $\mathrm{Rb}-\mathrm{Sr}$ isochronic diagram, yield a slope age of $1830 \pm 270 \mathrm{Ma}$ and ${ }^{87} \mathrm{Sr} /{ }^{86} \mathrm{Sr}$ initial ratio of $0.7045 \pm 0.0029$ and MSWD $=5.4$ (Fig. 8). The scattering of some of the points about the isochron may have been caused by uncompleted $\mathrm{Sr}$ isotope homogenization during the 
Table 1-U-Pb analytical data on zircon fraction of tonalite.

\begin{tabular}{|c|c|c|c|c|c|c|c|c|c|c|c|}
\hline \multirow[t]{2}{*}{$\begin{array}{l}\text { N/Sample } \\
\text { fraction } \\
\text { size } \\
\left(\mu_{\mathrm{m})}\right.\end{array}$} & \multicolumn{2}{|c|}{$\begin{array}{c}\begin{array}{c}\text { Conce } \\
\text { ntrations } \\
(\mathrm{ppm})\end{array} \\
\end{array}$} & \multirow{2}{*}{$\begin{array}{l}{ }^{206} \mathrm{~Pb}^{20} / \\
{ }^{204} \mathrm{pb}^{\mathrm{a}}\end{array}$} & \multicolumn{5}{|c|}{ Isotopic ratio s corrected for blank and com mon $\mathrm{Pb}^{\mathrm{b}}$} & \multicolumn{3}{|c|}{$\begin{array}{l}\text { Age } \\
\text { (Ma) }\end{array}$} \\
\hline & $\mathrm{Pb}$ & & & $\begin{array}{l}207 \mathrm{pb} / \\
200 \mathrm{pb}\end{array}$ & $\begin{array}{l}200 \mathrm{~Pb} / \\
{ }_{2006}^{200} \mathrm{pb}\end{array}$ & $\begin{array}{l}2010 \mathrm{pb} / \\
235 \mathrm{U} /\end{array}$ & $\begin{array}{l}2066 \mathrm{~Pb} / \\
228 \mathrm{U} /\end{array}$ & & $\mid \begin{array}{l}2079 \\
{ }^{235} \mathrm{~Pb} / \\
\mathrm{U}\end{array}$ & $\begin{array}{l}206 \mathrm{~Pb} / \\
{ }^{238} \mathrm{P} / \mathrm{U}\end{array}$ & $\begin{array}{l}2010 \mathrm{pb} / \\
200 \mathrm{pb}\end{array}$ \\
\hline $\begin{array}{l}22 / 1 \mathrm{~N}- \\
2678, \\
<100 \\
23 / \mathrm{N}- \\
2678, \\
>100 \\
\end{array}$ & 60.6 & 160.0 & $\mid 1736$ & $0.1308 \pm 1$ & $0.11581 \pm 1$ & $\begin{array}{l}6.0444 \pm 187 \\
6.2513 \pm 200\end{array}$ & $\begin{array}{l}0.3353 \pm 10 \\
0.3445 \pm 11\end{array}$ & 0.99 & $\begin{array}{l}1982 \pm 6.1 \\
2012 \pm 6.4\end{array}$ & $\begin{array}{l}1864 \pm 5.8 \\
1908 \pm 5.9\end{array}$ & $2108 \pm 0.8$ \\
\hline $\begin{array}{l}24 / \mathrm{IN}- \\
2678, \\
>100 \\
\text { A 70\% } \\
25 / \mathrm{IN}- \\
2678, \\
<100, \\
\mathrm{~A} 90 \%\end{array}$ & 43.7 & 99.8 & 566.9 & $0.1329 \pm 1$ & $0.14863 \pm 1$ & $6.7957 \pm 224$ & $0.3707 \pm 12$ & 0.95 & $\begin{array}{l}2085 \pm 6.9 \\
2114 \pm 7.6\end{array}$ & $2033 \pm 6.5$ & $2137 \pm 1.9$ \\
\hline
\end{tabular}

Table 2-Pb-Pb analytical data on tonalite and granodiorite.

\begin{tabular}{|c|c|c|c|c|c|c|c|c|}
\hline Sample & Rock & $\begin{array}{c}\mathbf{P b} \\
(\mathbf{p p m})\end{array}$ & $\begin{array}{c}\mathbf{U} \\
(\mathbf{p p m})\end{array}$ & $\begin{array}{c}\mathbf{T h} \\
(\mathbf{p p m})\end{array}$ & $\begin{array}{c}{ }^{206} \mathbf{P b} / \mathbf{P b} \\
{ }^{200} \mathbf{P b}\end{array}$ & $\begin{array}{c}{ }^{2004} \mathbf{P b} / \\
\mathbf{P b}\end{array}$ & $\begin{array}{c}{ }^{208} \mathbf{P b} / \\
{ }^{204} \mathbf{P b}\end{array}$ & $\begin{array}{c}{ }^{207} \mathbf{P b} / \\
{ }^{206} \mathbf{P b}\end{array}$ \\
\hline C-26 & Tonalite & 12.2 & 2.46 & 13.2 & 20.010 & 15.936 & 38.702 & 0.7964 \\
\hline SL-37 & Granodiorite & 18.2 & 2.75 & 9.37 & 18.700 & 15.793 & 36.227 & 0.8445 \\
\hline SL-64 & Granodiorite & 19.8 & 4.43 & 14.2 & 20.031 & 15.957 & 36.589 & 0.7966 \\
\hline
\end{tabular}

Table 3-Sm-Nd analytical data on tonalite and granodiorite.

\begin{tabular}{|c|c|c|c|c|c|c|c|c|c|c|}
\hline $\begin{array}{c}\text { Sampl } \\
\text { e }\end{array}$ & Rock & $\begin{array}{c}\text { Sm } \\
(\mathrm{ppm})\end{array}$ & $\begin{array}{c}\mathrm{Nd} \\
(\mathrm{ppm})\end{array}$ & $\begin{array}{l}{ }^{147} \mathrm{Sm} / \\
{ }^{144} \mathrm{Nd} \\
{ }^{2}\end{array}$ & Error & $\begin{array}{l}\frac{143}{143} \mathrm{Nd} / \\
{ }^{144} \mathrm{Nd}\end{array}$ & Error & $\begin{array}{c}\mathbf{T}_{\mathrm{dm}}(\mathbf{G A}) \\
(\mathrm{DePaolo}) \\
\end{array}$ & $\varepsilon_{\mathrm{Nd} d}(\mathbf{0})$ & $\varepsilon_{\mathrm{Nd}}(\mathbf{T})$ \\
\hline $\mathrm{IH}-26$ & Tonalite & 4.809 & 25.417 & 0.1144 & 0.0001 & 0.511587 & 0.000044 & $2.242 \pm 0.063$ & -20.50 & +3.02 \\
\hline $\mathrm{C}-01$ & Granodiorite & 0.937 & 6.992 & 0.0810 & 0.0001 & 0.511010 & 0.000036 & $2.344 \pm 0.039$ & -31.76 & +2.84 \\
\hline
\end{tabular}

Table 4-Rb-Sr analytical data on tonalite, granodiorite aplite and tonalite* (altered tonalite).

\begin{tabular}{|c|c|c|c|c|c|c|c|}
\hline Sample & Rock & $\begin{array}{c}\mathbf{R b} \\
(\mathbf{p p m})\end{array}$ & $\begin{array}{c}\mathbf{S r} \\
(\mathbf{p p m})\end{array}$ & $\begin{array}{l}{ }^{87} \mathrm{Rb} / \\
{ }^{86} \mathrm{Sr}\end{array}$ & \pm Error & $\begin{array}{l}{ }^{87} \mathrm{Sr} / \\
{ }^{86} \mathrm{Sr}\end{array}$ & \pm Error \\
\hline SL-02 & Tonalite & 41.4 & 447.0 & 0.2679 & .0038 & 0.71086 & .000 \\
\hline SL-20 & Tonalite & & 5.3 & 3139 & 546 & 71208 & \\
\hline SL-44 & Tonalite & & 14.6 & 3590 & 100 & 71364 & 07 \\
\hline S-20 & Tonalite & 5.7 & 486.2 & 0.5760 & 0.0160 & .72096 & 009 \\
\hline SL-30 & Granodi orite & 86.7 & 449.5 & 0.5590 & 0.0160 & 0.72028 & 014 \\
\hline SL-37 & Gran & 08.3 & 235.7 & 1.3350 & 80 & 500 & 12 \\
\hline SL-64 & $\mathrm{e}$ & 7 & 17.2 & 3680 & 51 & 71366 & 18 \\
\hline C-01 & Granodiorite & 58.3 & 951.1 & 0.1774 & 0.0015 & $\begin{array}{l}0.70788 \\
\end{array}$ & .00009 \\
\hline C-02 & Granodi orite & 86.6 & 535.8 & 0.4680 & 0.0130 & 0.71619 & 0.00008 \\
\hline SHN-04 & Granodi orite & 62.4 & 612.2 & 0.2950 & 0.0080 & 0.71158 & 0.00007 \\
\hline SLAP-01 & Aplite & 165. & 73.3 & 6.673 & \begin{tabular}{|l|}
0.1850 \\
\end{tabular} & 0.89812 & 0.00015 \\
\hline SLAP-02 & Aplite & 227.4 & 57.6 & 11.801 & 0.3230 & 1.04073 & 0.00010 \\
\hline SLAP-05 & olit & 236.0 & 72.4 & 9.693 & 0.2670 & 0.98650 & 0.00250 \\
\hline SLAPL-01 & olite & 143.5 & 74.4 & 5.671 & 0.1580 & 0.86859 & 0.00008 \\
\hline SLFC-06 & Ton alite* & 81.5 & 315.0 & 0.7500 & \begin{tabular}{|l|}
0.0210 \\
\end{tabular} & 0.724880 & 0.000070 \\
\hline SLFL-07 & Ton alite* & 101.0 & 528.4 & 0.5537 & $\begin{array}{ll}0.0077 \\
\end{array}$ & 0.718590 & 0.000200 \\
\hline SLFC-09 & Ton alite* & 185.8 & 416.3 & 1.2952 & 0.0183 & 0.738260 & 0.000280 \\
\hline SLFL-14 & Ton alite* & 67.6 & 612.1 & 0.3198 & 0.0046 & 0.712390 & 0.000100 \\
\hline
\end{tabular}

mineralization event or by subsequent disturbance of the isotope system associated with mineralization overprint and/or shear episodes. The altered tonalite exhibit a more radiogenic initial ${ }^{87} \mathrm{Sr} /{ }^{86} \mathrm{Sr}$ ratio than the fresh tonalite. The higher initial ${ }^{87} \mathrm{Sr} /{ }^{86} \mathrm{Sr}$ ratio of altered tonalite in relation to the expected low $\mathrm{Sr}$ isotopic composition of fresh tonalite, can be related to the overall effect of mineralizing fluid/rock interaction and $\mathrm{Sr}$ fractionation processes. K-Ar age determinations on biotite from the altered tonalite yield values ranging from 1794 to 1758 Ma (Table 5) comparable in time to those of the Maroni-Itacaiunas orogen, $\mathrm{Rb}-\mathrm{Sr}$ and $\mathrm{K}-\mathrm{Ar}$ mineral ages between 2,08 $\mathrm{Ga}$ and 1,76 Ga, reported by Montalvão and Tassinari 1984 and Tassinari 1996. Considering that the estimated temperature of mineralizing solutions was at least $300^{\circ} \mathrm{C}$ (Nogueira 2000), the $\mathrm{K}$-Ar results might reflect the cooling age of the hydrothermal event. Alternatively, based on regional geochronological information, it is possible to interpret the results as regional cooling ages or as apparent ages reflecting subsequent

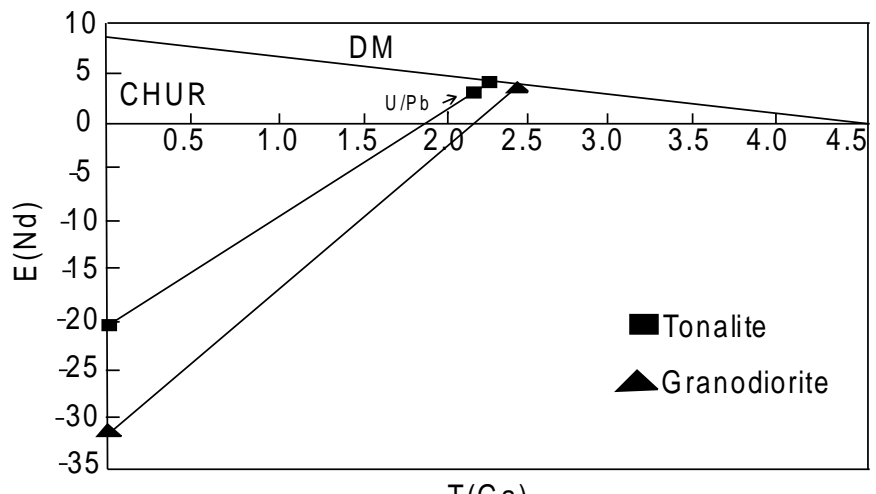

$\mathrm{T}(\mathrm{Ga})$

Figure 4-Nd vs. age diagram showing evolution lines for tonalite and granodiorite of the mine site.

Table 5-K-Ar biotite analytical data on altered tonalite.

\begin{tabular}{|l|c|c|c|c|c|c|c|}
\hline Sample & Rock & Mineral & $\mathbf{\%}$ & $\mathbf{\pm E r r o r}$ & $\begin{array}{c}\mathbf{A r}^{\mathbf{4 0}} \mathbf{R a d . 1 0} \\
(\mathbf{c c S T P} / \mathbf{g})\end{array}$ & $\begin{array}{c}\text { Ar Atm } \\
(\mathbf{\%})\end{array}$ & $\begin{array}{c}\text { Idade } \\
(\mathbf{M a})\end{array}$ \\
\hline SLFL-01 & Tonalite & Biotite & 7.3898 & 0.5482 & 863.73 & 0.53 & 1770.4 \\
\hline SLFP-21 & Tonalite & Biotite & 7.4669 & 0.5000 & 891.25 & 0.38 & 1794.1 \\
\hline SLFP-22 & Tonalite & Biotite & 7.3699 & 0.9054 & 852.39 & 2.09 & 1758.6 \\
\hline
\end{tabular}

isotopic disturbance during younger tectono-metamorphic activity (remobilization within the mineralized zone) related to the neighboring 1.76Ga felsic and alkaline bodies of the Falsino and Mapari suites (Tassinari et al. 1984).

FINAL CONSIDERATIONS The data obtained on granitoids of the Lourenço region are indistinguishable from previous geochronological results on similar rocks in other areas of the MaroniItacaiúnas Province. In the French Guyana, syntectonic granitoids and gneissic-migmatitic terranes of "Série Ille de Cayenne" yielded ages of 2.1-1.95 Ga, with $\mathrm{Sr}$ initial ratios around $0.7018-0.7024, \mu_{1}$ value of 8.2 and positive $\varepsilon_{\mathrm{Nd}}$ values (Teixeira et al. 1985, Milési et al. 1995). $\mathrm{U}-\mathrm{Pb}$ ages on detrital zircon zircons from metagraywackes and conglomerates from greenstone belt sequences gave ages between 2.25 and 2.1 Ga (Gibbs 1980, Milési et al. 1995, Gibbs and Olszewski 1982). In addition Vanderhaeghe et al. (1998) constrained an episode of trondhjemitic magmatism at $2.17 \mathrm{Ga}$ followed by the emplacement of calc-alkaline intrusions at $2.14-2.11 \mathrm{Ga}$ and a late high-K magmatism at 2.09-2.08 Ga. Moreover the volcanism of the Vila Nova Group in northeast Pará and the Paramaca Group in French Guyana, both related to the greenstone belt sequences, yield Sm-Nd isochronic ages of 2.26 and 2.1 Ga respectively (McReath and Faraco 1997, Gruau et al. 1985).

The isotopic data available for the Lourenço Au-District and neighboring regions in Amapá and French Guyana, strongly suggest a geodynamic crustal evolution model, based on the development of a calc-alkaline magmatic arc in the time interval (2.25-2.0). This can be explained by subduction of oceanic lithosphere in the beginning of the collision between a continental mass, composed at that time by the Central Amazonian Province - Carajás-Iricoumé Block (Tassinari 1996) and the West African craton (Tassinari and Macambira 1999). Therefore the most plausible tectonic setting which necessarily includes the Salamangone gold deposit was genetically related to convergent tectonics associated to plate movement and supercontinental aggregation during the Paleoproterozoic.

Acknowledgements This work was supported by FAPESP São Paulo, Brazil (grant no 96/3942-0) and it is also a contribution to IGCP-426 (Granite Systems and Proterozoic Lithospheric Processes). 
(a)

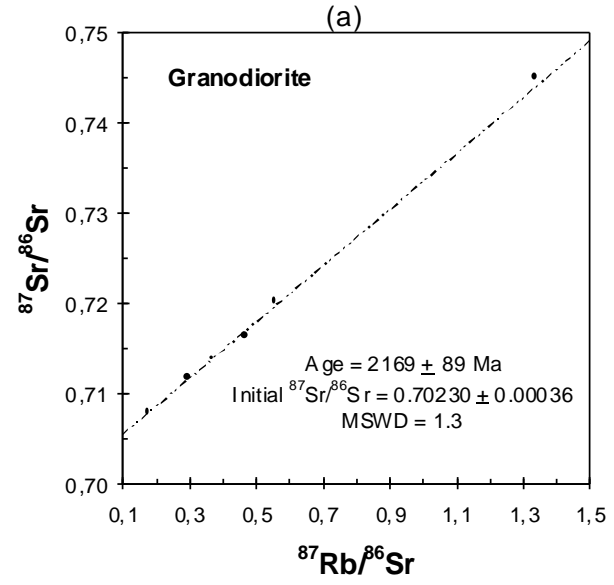

(c)

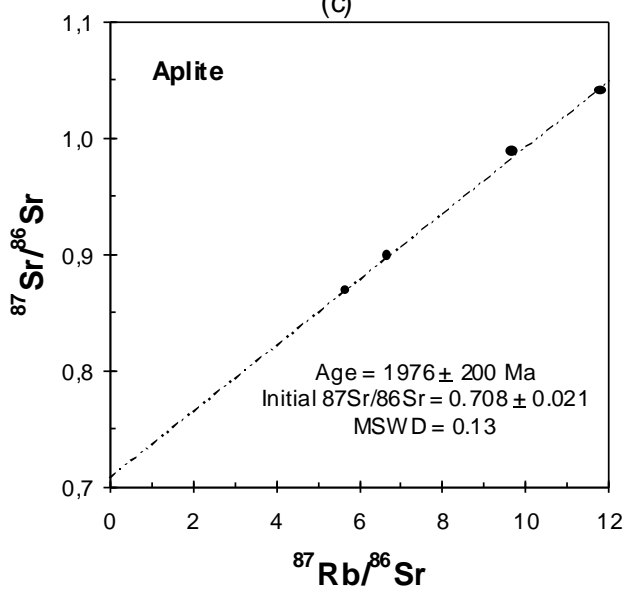

(b)

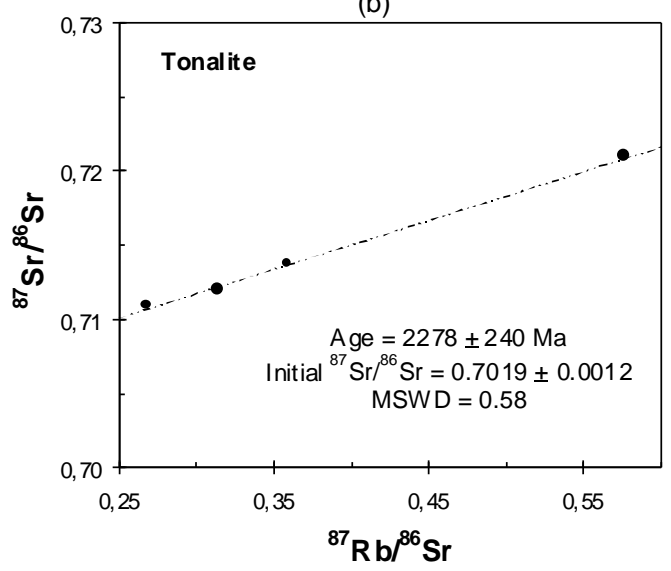

(d)

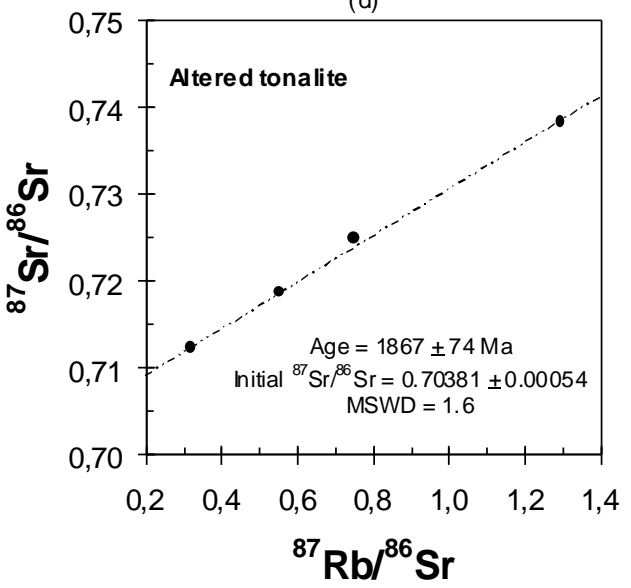

Figure 5-Rb-Sr whole rock isochron for: (a) granodiorite, (b) tonalite, (c) aplite and (d) altered tonalite (host rocks of the Salamangone mineralization).

\section{References}

Almeida F.F.M. 1978. A evolução dos craton Amazonico e de São Francisco comparada com a de seus homólogos do Hemisfério Norte. In: SBG, Congr. Bras. Geol., 30

Recife, Anais, .6:2393-2407.
Amaral G., Cordani U.G., Kawashita K., Reynolds J.H. 1966. Potassium-Argon dates of basaltic rocks from Southern Brazil. Geochim. Cosmoch. Acta, 30:159-189.

Callan N.J. \& Spooner, E.T.C. 1989. Archean Au quartz vein mineralization hosted in a tonalite-trondhjemite terrane, Renabie mine area, Wawa, North Ontario, Canada. Econ. Geol. Monograph, 6:9-18

Callan N.J. \& Spooner, E.T.C. 1998. Repetitive hydraulic fracturing and shear zone inflation in an Archean granitoid-hosted, ribbon banded, Au-quartz vein system, Renabie area, Ontario, Canada. Ore Geol. Rev., 12:237-266.

Cassidy K.F., Groves D.I., Mcnaughaton N.J. 1998. Late archean granitoid-hosted lode-gold deposits, Yilgarn craton, Western Australia: Deposits characteristics, crustal architecture and implication for ore genesis. Ore Geol. Rev., 13:65-102.

Choubert B. (1974). Le precambrian de guyenes. Memoire du BRGM. Paris, II, 81-211. Gibbs A.K. 1980. Geology of Barama-Mazaruni Supergroup of Guyana. Harvard. Univ.
Microfilms Intern. Ann. Aarbor MI, n.81022054, PhD Thesis, 387p.

Gibbs A.K. \& Olszewski Jr. W.J. 1982. Zircon U-Pb ages of Guyana greenstone-gneiss terrane. Prec. Research, 17:199-214.

Gruau G., Martin H., Leveque B., Capdevilla R. 1985. Rb/Sr and Sm/Nd geochronology of Lower Proterozoic granite-greenstone terrain in French Guyana, South America. Prec. Research, 30:63-80.

Krogh T.E. 1982. Improved accuracy of U-Pb zircon by the creation of more concordant systems using an air abrasion technique. Geochim. Cosmoch. Acta, 46:637-649. and extraction of $\mathrm{U}$ and $\mathrm{Pb}$ for isotopic age determination. Geochim Cosmoch. Acta,

Lima M.I.C., Issler R.S., Andrade A.R.F., Montalvão R.M.G., Guimarães G., Silva G.G. 1974. Geologia da Folha SA-22 Belém. In: Brasil, DNPM, Projeto RADAM. Rio de Janeiro. Levantamento de Recursos Naturais, 5:1-60. Lima M.I.C., Bezerra P.E.L., Araújo H.J.T. 1991. Sistematização da geologia do Amapá. In:
SBG, Simp. Geol. Amaz., 3, Belém, Anais, 322-335.

Ludwig K.R. 1999. Isoplot/Ex, vs 2.10. A Geochronological Toolkit for Microsoft Excel. Berkeley Geoch. Center. Spec. Publ. No. 1a. 49p.

Macreath I. \& Faraco M.T.L. 1997. Sm/Nd and Rb/Sr systems in parts of the Vila Nova metamorphic suite, northern Brazil. In: South- American Symposium on Isotope Geology, Brazil, Actas, 194-196.

Milési J.P., Ledru P., Frybesse J.P., Dommanget A., Marcoux, E. 1992. Early Proterozoic ore deposits and tectonic of the Birimian Orogenic Belt, West Africa. Prec. Research, 58:305-344.

Milési J.P., Egel E., Ledru P., Verhet Y., Thiéblemont D., Cocherie A., Tegyey M., MartelJantin B, Lagny P. 1995. Les minéralisations du Nord de la Guyane Française dans leur cadre géologique. Chron.Rech.Min, 518:5-58.

Montalvão R.M.G. \& Tassinari C.C.G. 1984. Geocronologia precambriana do Território Federal do Amapá (Brasil). In: Symp. Amaz., 2, Manaus, Anais, 53-57.

Nogueira S.A.A. 2000. Estudo da mineralização filonar quartzo-aurífera do Morro Salamangone, Distrito Aurífero de Lourenco, Amapá. Instituto de Geociências, Universidade de São Paulo, Ongoing Ph.D. thesis.

Oberthür T., Vetter U., Davis D.W., Amanor J.A. 1998. Age constraints on gold mineralization and Paleoproterozoic crustal evolution in the Ashanti belt of southern Ghana. Prec. Research, 89:129-143.

Pearce J.A., Harris N.B.W., Tindle A.C. 1984. Trace Elements discrimination diagrams for the tectonic interpretation of granitic rocks. J. Petrol., 25:956-983.

Steiger R.H. \& Jaeger E. 1977. Subcommission on Geochronology: convention of the use of decay constants in geo and cosmochronology. A.A.P.G, Studies in Geology, 67-71. Tassinari C.C.G., Teixeira W., Siga Jr. O. 1984. Epocas metalognéticas relacionadas a granitogênese do Craton Amazonico. In: SBG, Congr. Bras. Geol., 33, Rio de Janeiro, Anais, 6:2963-2977.

Tassinari C.C.G. 1996. O mapa geocronológico do Cráton Amazônico no Brasil: Revisão dos dados isotópicos. Inst. de Geociências, Universidade de São Paulo, Tese de Livre Docência, 139p.

Tassinari C.C.G. \& Macambira M.J.B. 1999. Geochronological Provinces of the Amazonian Craton. Episodes, 22(3):174-182.

Teixeira W., Kawashita K., Taylor P.N., Ojima S.K., Vieira A.G. 1985. Reconhecimento geocronológico da Guyana Francesa: novos dados, integração e implicações tectônicas. Simpósio de Geologia da Amazônia, II, Belém, Anais, 194-207.

Teixeira W. Tassinari C. C. G., Cordani U. G., Kawashita K. 1989. A review of the geochronology of the Amazonian Craton: tectonic implication. Prec. Research, 42:213-227.

Terraconsult A. G. 1986. Mineração Novo Astro S.A. Amapá Exploration Project. Final Report.

Vanderhaeghe O., Ledru P., Thiéblemont D., Egal E., Cocherie A. Tegyey M., Milési J.P. 1998. Constrasting mechanism of crustal growth. Geodynamic evolution of the Paleoproterozoic granite-greenstone belts of French Guyana. Prec. Research, 92:165-19.

Contribution IGC-141

Received March 2, 2000 Accepted for publication May 16, 2000 